\title{
PSYCHOLOGICAL AND PEDAGOGICAL ASPECTS OF THE FORMATION OF THE PSYCHOEMOTIONAL SPHERE OF ADOLESCENTS IN CONDITIONS OF THE MODERN EDUCATIONAL ENVIRONMENT
}

\section{Bartienieva I. A., Nozdrova O. P.}

\section{INTRODUCTION}

The problems of young people have always worried teachers, psychologists, but they have become especially urgent today. An increase in the level of education and material well-being of members of society expanded the possibilities for the development and satisfaction of the spiritual and material needs of the younger generation, but made more difficult to form rational desires and aspirations.

The complex modern socio-economic conditions in the country have led to a decline in the prestige of education, a change in value orientations. Certain shortcomings in the education system also adversely affect the formation of an emotionally positive attitude in children towards learning, towards school, which would encourage their desire to learn, gain knowledge, develop creative powers and abilities. However, modern conditions of economic development require highly qualified, knowledgeable, creatively thinking personnel. Achievement of a high level of knowledge, skills and abilities is impossible without an emotionally positive attitude to learning.

When we watch the sunrise, read a book, listen to music, search an answer to the question that had been arisen, or dream about the future, then, along with various forms of cognitive activity, we show our attitude to the world around us. The book being read, the work being done can make us happy or sad, cause pleasure or disappointment. Joy, sadness, fear, delight, annoyance - these are various feelings and emotions.

Feelings and emotions depend on the characteristics of reflected objects. An objective relationship develops between a person and the surrounding world, which becomes the subject of feelings and emotions. In emotions and feelings, satisfaction or dissatisfaction of a person with his behaviour, actions, thoughts, statements, and activities is also manifested. 
Emotions and feelings are a kind of personal attitude of a person to the surrounding reality and to himself.

In adolescence, there is a significant development of the psychoemotional sphere. The range of phenomena to which the adolescent is not indifferent is growing, the range of interests is expanding, and against this background, the shortcomings of the development of the emotional sphere also become more and more clearly manifested. This may be an insufficient internal connection between the perception and assessment of any phenomenon of the surrounding world and the ability to act in accordance with this assessment. At the same time, the energy of a teenager finds relaxation only in emotional manifestations. Defects in the development of the emotional sphere include superficiality of feelings, poverty of emotional life.

Defects of the emotional sphere are very significant for a person because the mechanism of emotions is necessary for the regulation of behaviour and activity, and the better this mechanism functions, the more stable is a person's mental activity, the more harmonious his behaviour.

This means that knowledge of the characteristics of the psychoemotional sphere of a teenager, mastering of methods of their diagnosis, the use of effective ways of correcting deficiencies will help the teacher, parents, psychologist in working with age category under consideration.

\section{The essence of the concept of "emotions" and their significance for the child mental development}

"Emotions are the content of the human soul", wrote to K.D. Ushinsky. In the book "Man as a subject of education" he expressed, in our opinion, a very precise thought about the essence of feelings and emotions: "Nothing neither our words, nor thoughts, nor even our actions express so clearly and truly ourselves and our relationship to the world as our feelings; in them one can hear the nature not of a separate thought, not of a separate decision, but of the whole content of our soul and its structure. In our thoughts we can deceive ourselves, but our feelings will tell us what we are: not what we want to be, but what we really are",

When the complex social needs that arise in the process of personality formation are satisfied, higher feelings arise (when spiritual needs are satisfied); when organic needs are satisfied, lower feelings (emotions)

1 Ушинский К.Д. Сочинения : в 9 т. Москва, 1950. Т. 2 : Человек как предмет воспитания. С. 117-118. 
arise. Emotions are often situational in nature and express an individual's assessment of a certain situation related to the satisfaction of a person's needs at the moment. In humans, they manifest themselves in a variety of emotional states, which can be stenic (increase a person's vital activity, his activity) and asthenic (reduce a person's vital activity, his activity). There are no feelings that could arise without an emotional reaction.

Emotions include affects, moods, and addictions. Mood is an emotional state that is indicated for a long time in all human behaviour, all his thoughts, and experiences. Mood factors are: facts of life; situation; the mood of the people around; physical state.

Affect is an emotional short-term explosion, which is characterized by significant changes in consciousness, a violation of volitional control. Outwardly it manifests itself in unusual activity, expressive gestures, loudness, stiffness, numbness.

Addiction is an emotional state associated with a persistent aspiration of a person to a certain object. This is a psychological phenomenon that is not limited to the emotional sphere, but affects volitional and cognitive processes $^{2}$.

In psychology, there is an information theory of emotions - a concept according to which emotions are determined by any actual need and the possibility of its satisfaction, characterized by the probability of achieving a goal. An increase in probability as a result of the arrival of new information generates positive emotions, a decrease in probability leads to negative emotions.

In the end of the XIX century beginning of XX century. Russian pedagogue and psychologist P.F. Lesgaft developed the concept of "school types", which was based on observations of differences in the behaviour of children in terms of emotional attitude towards peers, adults, and the learning process. He identified the following types: hypocritical, ambitious, good-natured, softly downtrodden, maliciously downtrodden, and oppressed ${ }^{3}$. Familiarity with the characteristics of each of these types greatly facilitates the teacher's understanding of the psychology of students, their emotional manifestations in educational activities.

2 Гамезо М.В., Домашенко И.А. Атлас по психологии : информационнометодические материалы к курсу «Общая психология» : учебное пособие для студентов педагогических институтов. Москва : Просвещение, 1986. 272 с.

Лесгафт П.Ф. Избранные педагогические сочинения / сост. И.Н. Решетень. Москва : Педагогика, 1998. 400 с. 
Let us consider the views of various scientists in the field of pedagogy and psychology on the problem of emotions.

S.L. Rubinstein believes that feeling is a person's attitude to the world, to what he experiences and does, in the form of an experience. The experience of this relationship of a person to the environment is the sphere of feelings or emotions. Emotions express the state of the subject and his attitude to the object, and also differ in polarity, that is, they can be positive or negative ${ }^{4}$.

Human emotions have been comprehensively studied by the psychologist K. Izard ${ }^{5}$. He believes that emotions arise as a result of changes in the nervous system, which can be caused by internal or external events.

Negative emotions disorganize activities which lead to their occurrence, but organize actions aimed at reducing or eliminating harmful influences.

K.K. Platonov adheres to a position that is closer to us: emotions don't reflect objects, phenomena, but reflect objective relations of objects, phenomena to the needs of a person; therefore, they evoke in the mind not an image of an object, but experiences ${ }^{6}$.

N. Groth ${ }^{7}$ identified six functions of emotions, on the base of theoretical literature in the field of psychology and pedagogy.

1) The function of assessment, that is, human emotions are a language or a system of signals through which the subject learns the value of current events from the point of view of necessity.

2) Function of motivation.

3) Disorganizing function (E. Claparede) - the ability of emotions to disrupt purposeful activity.

4) Fixing - inhibition (P.K. Anokhin), trace formation (A.N. Leont'ev), reinforcement (P.V. Simonov) - the ability of emotions to leave traces in the experience of an individual.

${ }^{4}$ Рубинштейн С.Л. Основы общей психологии. Москва, 1946. 430 с.

${ }^{5}$ Изард К. Эмоции человека / пер. с англ. Москва : изд-во МГУ, 1980. 440 с.

${ }^{6}$ Кондрашова Л.В., Соколова Л.Е. Формирование эмоциональной культуры старшеклассников средствами учебно-воспитательного процесса. Кривой Рог, $1994.86 \mathrm{c}$.

7 Психология эмоций / под ред. В.К. Вилюнаса, Ю.Б. Гиппенрейтер. Москва : изд-во МГУ, 1984. 288 с. 
5) Anticipatory function - actualization of traces usually anticipates the development of events and the emotions arising in this case signal about a possible outcome, pleasant or unpleasant (A.V. Zaporozhets).

6) Heuristic function (O.K. Tikhomirov).

\section{Psychological features of adolescence}

The middle school age (from 9-10 to $14-15$ years) is usually called adolescent in psychology. This is the period between childhood and adulthood. The following traits are characteristic for a teenager: heightened sensitivity and irritability, anxiety, easy excitability, capriciousness, dissatisfaction with oneself and others, disobedience, feeling of loneliness and misunderstanding, frustration, aggressiveness, low efficiency, antisocial actions.

Modern adolescents have become more pragmatic, the importance of material values has sharply increased for them, and various categories of difficult adolescents are characterized by the absence of life goals, impoverishment, narrowing and deformation of the time perspective. It is known that the values of adolescent society can be negative and are expressed in the denial of socially norms approved by adults. In this regard, it is obvious that for normal socialization and the formation of a healthy lifestyle, for adolescents should be formed such ideals, values and life goals that would contribute to the positive development of the personality.

Problems arising in this age group may be caused by searches or difficulties associated with basic needs satisfaction: physiological; psychological safety ("grouping reaction"); independence and emancipation from parents; attachment, success, verification of one's capabilities, self-realization and development of one's own "I".

As for adolescent psychiatrists, in addition to the traditional for this age accentuations of character, they most often have to deal with selfdestructive (alcoholism, drug addiction, toxicomania, suicide) behaviour or with aggressive behaviour towards others. In addition, in recent years, social deviations (deviations from the norm) associated with mysticism; occultism and totalitarian religious sects have become increasingly common.

The child needs help in finding personal mechanisms for life regulation, allowing them to successfully resolve the contradictions that arise. The absence or insufficient development of the ability for selfregulation enhances the directivity of the adolescent's actual needs and emotions associated with failure in their realization, contributes to the 
fixation of a negative emotional state in combination with persistent somatic changes in the body. A vicious circle is created: failure in the implementation of actual activity - negative emotions - defensive automatisms - fixation of negative emotions - unfavourable somatic changes in the body - increased negative emotions - fixation of painful somatic manifestations. The likelihood of the formation of such a vicious circle increases in critical life situations that require a child (adolescent, young man) to be more active in the field of self-regulation. By organizing an adequate social environment, the teacher simultaneously creates conditions for the development of the child's social skills that can support his social adaptation.

The psycho-emotional sphere of a younger adolescent is often a bundle of contradictions and lies and in the fact, showing rudeness and intolerance, they are at the same time very vulnerable. Their mood can change in a short period of time from cheerful to gloomy.

Closely related to mood and emotional state is the adolescent's ability to perform not only difficult, but also familiar, well-known or favourite work: sometimes they work with inexhaustible enthusiasm; sometimes they are slow and apathetic. Therefore, younger adolescents need, first of all, a sparing regimen, prevention of various overloads due to increased fatigue and irritability. Failure to comply with a rational mode of life, excessive mental, physical stress and strong emotional experiences can ultimately lead to neuropathy and unhealthy forms of behaviour.

Sexual differences in the behaviour of younger adolescents often boil down to the fact that girls, despite their increased impressionability, have a predominantly drowsy, apathetic state, and boys have relatively more active behaviour and negative actions in relation to adults and comrades.

Older adolescents are less irritable than younger and middle ones; their mood is often cheerful, optimistic. Instability and self-doubt are replaced by increased and often overestimated self-esteem.

Comprehensively studied adolescence S. Hall. He believed that the adolescent stage in personality development corresponds to the era of romanticism in the history of mankind. This is an intermediate stage between childhood - the era of hunting and gathering, and adulthood the era of a developed civilization. This period is full of stress, conflict, instability, confusion, enthusiasm, contrasts. This is the period of "storm and rush".

S. Hall identified the main contradictions in adolescence. In adolescents, excessive activity can lead to exhaustion, insane gaiety gives way to despondency, self-confidence turns into shyness and cowardice, selfishness alternates with altruism, high moral aspirations 
are replaced by low motives, passion for communication turns into isolation, subtle sensitivity develops into apathy, lively curiosity - in mental indifference, passion for reading - in disregard for it, the desire for reform - in the love of routine, passion for observation - in endless reasoning. Having overcome the crisis of self-awareness, a person acquires a sense of individuality.

E. Spranger described three types of development in adolescence. The first is characterized by a sharp, stormy, crisis course, when adolescence is experienced as a second birth, as a result of which a new "I" arises. The second type is smooth, slow, gradual growth, when a teenager joins adult life without deep and serious shifts in his own personality. The third type the adolescent himself actively and consciously forms and educates him, overcoming by an effort of will internal anxieties and crises. It is typical for people with a high level of self-control and self-discipline.

The transformation of an adolescent into a young man is manifested in a change in the basic attitude in relation to the world around him: the negative phase of life-denial, inherent in the pubertal stage, is followed by the phase of life-affirmation, characteristic of adolescence.

The main features of the negative phase: increased sensitivity and irritability, anxiety, easy excitability, aggressiveness, capriciousness, dissatisfaction with oneself, attraction to secret and forbidden, disobedience, feeling of loneliness, disappointment. Common behaviours are "passive melancholy" and "aggressive self-defence". The consequence of all these phenomena is a decrease in performablity, emotional instability, and isolation from others or a hostile attitude towards them.

L.S. Vygotsky considered the feeling of adulthood to be the central neoplasm of adolescence. The teenager begins to feel like an adult, strive to be one. Although there is still no full-fledged adulthood. The great psychologist also attributed the development of reflection and selfawareness to the neoplasms of this age. He considered to be the most striking interests (dominants) "egocentric dominant" (interest in one's own personality), "expansion dominant" (setting on large scales that are more acceptable to him than closed-by), "effort dominant" (craving for resistance, overcoming, to volitional stress), "the dominant of romance" (striving for the unknown, risky).

Getting rid of parental care is a universal psychological goal of adolescence. The transition period is associated with the fact that parental care is gradually replaced by dependence on other institutions of socialization (while maintaining emotional ties with the family).

Communication is the leading type of activity. Characteristic is the dominance of the child community over the adult one. Relationships with 
peers stand out in the sphere of personal life, isolated from the influence, intervention of adults.

A need for knowledge of one's own characteristics, interest in oneself and reflections on oneself is a characteristic feature of adolescents. They can be emotionally offended, suspicious, distrustful, aggressive, and extremely sensitive to judgments in their address. Chronic failures provoke self-doubt, a decrease in the level of claims, or, conversely, the desire to prove to everyone and to themselves their capabilities.

The motives for learning activity are unsteady and can change. Like any activity, educational activity is multi-motivated, and therefore general social, cognitive, and also private motives can be intertwined in it. It should be noted that the desire of a teenager to acquire knowledge can be combined with a negative attitude towards learning due to his lack of positive motivation, lack of skills, lack of volitional qualities.

The initial signs of pedagogical neglect usually manifest themselves in a variety of changes in the emotional sphere - instability of emotions, low mood, irritability, negative attitude towards the discipline in which the adolescent has no success, towards the relevant teacher, etc. Chronic emotional tension in such cases usually finds a way out in increased communication with peers outside of school. The character of a teenager gradually changes, a negative experience is acquired, and the personality can generally change in a negative direction.

It is known that the most stable features of essential personality traits are expressed in character. In the structure of character are distinguished content (properties that express an attitude towards other people, oneself, work, things, etc.) and the form of external manifestation of relations in the form of actions, deeds, facial expression, posture, gait, speech, etc.

The peculiarity of character in adolescence is usually manifested in its "sharpening", accentuation, caused by social factors - the complication of relationships with surrounding people and biological shifts - neuroendocrine restructuring that underlies puberty. Insufficient consideration of character traits in puberty contributes to the emergence of tense, conflicting relationships in the family and school. Let us dwell on some types of character accentuation ${ }^{8}$.

Hyperthymic type. Adolescents of this type are characterized by mobility, sociability, and a tendency to mischief. They always make a lot of noise in the events taking place around them, they love the restless companies of their peers, in spite of $h$ good general abilities, they show

Колесов Д.В., Мягков И.Ф. Учителю о психологии и физиологии подростка. Москва : Просвещение, 1986.80 с. 
restlessness, lack of discipline, they study unevenly. Their mood is always good, elated. They often have conflicts with adults, parents, and teachers. These teenagers have many different hobbies, but these hobbies are usually superficial and quickly pass. Teenagers of the hypertimal type often overestimate their abilities, are too self-confident, strive to show themselves, boast, and impress others. They are easily excitable and in certain situations are aggressive, irritable and angry.

Cycloid type. It is characterized by increased irritability and a tendency to apathy. Teenagers of this type prefer to be at home alone instead of communicate with their peers. They take even minor troubles hard, react extremely irritably to comments. Their mood periodically changes from elevated to depressed (hence the name of this type) with periods of about two to three weeks.

Labile type (emotionally labile). This type is extremely changeable in mood that is often unpredictable. Reasons for an unexpected change in mood can be the most insignificant, for example, accidentally dropped offensive word, someone's unfriendly look. All of them are capable of sinking into despondency and gloomy mood in the absence of any serious troubles and failures.

Psychasthenoid. This type is characterized by increased suspiciousness and moodiness, fatigue and irritability. In childhood, along with some shyness, he shows a tendency to reason and intellectual interests exceeding their age limit. At the same age, various phobias arise: fear of strangers, new objects, darkness, of being left alone at home, etc. Fatigue is present especially when performing a difficult task. Uncertainty and anxious suspiciousness about the future of oneself and one's loved ones is the dominant feature. This type is attractive on the one hand for its accuracy, seriousness, conscientiousness, reliability, loyalty to the promises made, but the repulsive in him is indecision, lack of initiative, a certain formalism, a tendency to endless reasoning, the presence of obsessive ideas, "self-delusion".

Sensitive type. $\mathrm{He}$ is characterized by an increased sensitivity to everything: to that which pleases, and to that which saddens or frightens. These teenagers do not like big companies, too gambling, active, mischievous games. They are usually shy and timid in front of strangers and therefore often give the impression of being unsociable. They are open and sociable only with those who are familiar to them; they prefer communication with kids and adults to communication with their peers. They are obedient and show great affection for their parents. In youth, such adolescents may experience difficulties in adapting to the circle of their peers, as well as an "inferiority complex". At the same time, these 
same adolescents develop quite early a sense of duty, high moral requirements for themselves and surrounding persons. They often compensate for deficiencies in their abilities by choosing difficult activities and increased diligence. These teenagers are picky in finding friends and acquaintances; they show great affection in friendship, adore older friends.

Psychasthenic type. These adolescents are characterized by early intellectual development, a tendency to think and reason, to introspect and assess the behaviour of other people. Such adolescents, however, are often more powerful in words than in deeds. Self-confidence in them is combined with indecision and categorical judgments - with hasty actions taken just at those moments when caution and prudence are required.

Unstable type. He is sometimes incorrectly characterized as weakwilled, going with the flow. Adolescents of this type show an increased inclination and craving for entertainment, as a rule indiscriminately, as well as for idleness and indolence. They do not have any serious interests, including professional, they hardly think about their future. This instability manifests itself in relation to external influences. They do not like to study, work, and openly talk about it. They are interested in films that do not require intellectual exertion. In a peer group, they are in the hands of the leaders and are complicit in desperate acts and delinquency, which are often committed in a state of intoxication. These adolescents are prone to affective outbursts; they often have disinhibition of drives (food, sexual). So, at recess, such a teenager, running to the buffet and not seeing there the food that he wanted to take, can go to the nearest store and skip lessons.

Conformal type. This type demonstrates thoughtless, uncritical, and often opportunistic submission to any authorities, to the majority in the group. Such adolescents are usually prone to moralizing and conservatism, and their main life credo is "to be like everyone else". This is a type of opportunist who, for the sake of his own interests, is ready to betray a comrade, to leave him in difficult times, but no matter what he does, he will always find a justification for his action, and often more than one.

Hypotim. Its dominant feature is a constantly low mood, a tendency to depressive affects. Hyptim's mood is just as constantly changing as that of Hypertim, but only these changes are with a minus mark. In childhood, such a child is almost always lethargic, lives without any special joys, is offended at everyone, and above all at his parents. Hypotim is endowed with conscientiousness and a critical view of the world, but at the same time he is prone to resentment, vulnerable, 
looking for a manifestation of ailments, various diseases, shows an almost complete lack of interests and hobbies.

More rarely, there are adolescents with an anxious and suspicious type of character accentuation. They usually study well, are disciplined, and do not bother teachers. However, these teenagers are hard for themselves. Endless doubts about the correctness of their actions, about completing tasks exhaust them. Uncertainty in their strengths, capabilities, especially in physical terms, fetters them and does not give them the opportunity to express themselves in full. They are worried about the future, they see obstacles and difficulties in everything, although they solve all issues logically, correctly, but, having done, they doubt and assume that it could have been done better. Their answers in the lessons, as a rule, are logical, evidence-based, and exhaustive. They are prone to endless mental reasoning, they like to solve all kinds of abstract problems, and they do not like to engage in physical labor. They perceive the world around them in a pale, simplistic way, looking for a cause-and-effect relationship in everything. They do not have the brightness and strength of emotional experience in the perception of the environment, although at the same time they are very sensitive and vulnerable.

There are also adolescents whose character is distinguished by isolation, distrust, and emotional coldness. They find it difficult to find common contact with peers and are hardly upset by their isolation. Often, these schoolchildren show interest in any one academic discipline (mathematics, astronomy, etc.) and show deep knowledge in it. They read serious scientific works on a subject of interest and are deeply fond of it. In other academic disciplines, their knowledge is modest.

The external indifference of such children, the simplified behaviour and manifestations of emotions make them invisible. In a number of cases, teachers notice the abilities and successes of such a teenager in a particular discipline and recommend that parents intensively develop these abilities. However, this should not always be done, because exaggerated abilities in one direction make a person one-sided.

Intrapersonal and interpersonal conflicts lead to neurotic manifestations, which, as a rule, are not diagnosed. Emerging fears (more often on the basis of punishment), various kinds of fears are transformed into constant anxiety; lability of mood, irritability, increased excitability. All of these and other signs can be regarded as the second stage of pedagogical neglect. At this stage, the most diverse, even insignificant, objective or subjectively judged adverse effects often cause an affective reaction in the adolescent. The style of behaviour changes accordingly. It often lacks rationality, and the actions of a teenager 
become little understandable to others. The personality becomes unstable to external influences.

Intrapersonal and interpersonal conflicts usually worsen and gradually form into a pathological character - this indicates a new, third stage of pedagogical neglect. Characterological changes are manifested either in a pronounced degree of accentuation, more often in the form of conformal, emotionally unstable, excitable, less often hyperthymic, hysterical deviations, etc., or in the form of pronounced traits of a pathological nature.

\section{Emotional maturity}

Emotional maturity is understood as the correspondence of the emotional manifestations of an adult to the norms accepted in a relevant society (A. Reber, P. Fress); as the correspondence of emotional manifestations of an adult not only to the expectations of society, but also to the needs, values, interests of the subject (A.G. Maslow); as the correspondence of emotional behaviour to ideas about the norm for a certain age (A. Maurer).

What these definitions have in common is a view of emotional maturity as the ability to adequately react emotionally, taking into account the age period of a person's life, i.e. its development in specific social conditions.

Human emotions have a psychophysiological (natural) and social basis in their development. The natural basis is based on those psychophysiological features that reflect the adequacy of the dynamics of development of emotions at a given age. The social basis reflects the experience of the developing personality's emotional relationship to the surrounding world. Consequently, by emotional maturity we mean the integrative quality of the personality, which characterizes the degree of development of the emotional sphere at the level of the adequacy of the emotional response in certain socio-cultural conditions. Signs of emotional maturity include the features of emotional expressiveness, emotional self-regulation, and empathy.

The indicators of emotional expressiveness are: the ability to adequately display one's emotional state in facial expressions, pantomime, expressive actions, intonation. The indicators of emotional self-regulation are the management of emotions in accordance with the situation and expediency, the ability to cope with emotional reactions in socially accepted ways. Empathy indicators are: the ability to understand the world of another person's experiences, to emotionally respond to her experiences, to use these abilities in communication. 
There are internal and external factors in the development of emotional maturity during adolescence. Internal factors include the individual characteristics of a person, individual typological characteristics of the personality, the formation of an adequate "I concept". External factors include the level of social and environmental stability, the speed of changes in the system of social roles, the quality of family interaction, social circle, and frequency of social contacts.

The personal level of manifestation of emotional maturity is considered by us as the result of the inner activity of the individual, aimed at mastering himself, at transforming the inner world. The interpersonal level of manifestation of emotional maturity is considered by us as the result of external activity, which is aimed at transforming the external world and manifests itself in communication. We conditionally called these levels of manifestation of the components of emotional maturity introdirectionality (focus on the internal state) and extradirectionality (focus on the external social environment). The prefixes "intro" and "extra" characterize different levels of manifestation of each component of emotional maturity, which complement each other.

Thus, introexpression is involuntary manifestations of emotions in facial expressions, movements, intonations, which also perform the function of discharge, relief, regulation of the process of excitement caused by emotional experiences. It is possible to interpret the involuntary expression of emotional states as an action aimed at organizing internal activity. In turn, the purposeful expression of emotions, the use of special techniques for a more accurate expression of a real or desired emotional state is used only in communication. This means that the ability to correctly convey one's emotional state in communication is one of the signs of extra-expressiveness.

The personal level of emotional maturity (intro self-regulation) is the ability to regulate one's own reactions, states, processes in accordance with the situation and expediency. It is achieved due to the improvement of techniques for suppressing unwanted reactions, stimulating the desired activity. Extra self-regulation - the ability to influence the behaviour of other people, mastery of methods of direct and indirect influence on the interlocutor.

Introempathy is the ability to understand the emotional state of the people around, the ability to sympathize and empathize with them, to understand the factors of their behaviour. Extraempathy is the ability to 
adequately use these skills as a way of regulating relationships in communication ${ }^{9}$.

\section{CONCLUSIONS}

The study of the characteristics of psychoemotional development of adolescents is relevant in modern times for many reasons. It is in adolescence that the active formation of the psychoemotional sphere takes place. The harmony of a person with himself and with the world around him depends, in many respects, on the formation and development of the emotional sphere.

The analysis of the psychological and pedagogical literature made it possible to make some generalizations.

Emotions are a mental reflection by the human brain of the needs of the body, as well as its satisfaction at the moment. Emotion is an indicator of a personal attitude to an object, phenomena, and situation.

Feelings are the highest form of development of emotions. Feelings arose when the human mind interacted with emotions. Feelings, forming in activity and developing in it, become the stimuli of actions, motives of actions. The education of feelings should be carried out in an indirect way.

Emotions have a significant impact on the course of learning activities. The role of emotions increases in the case when they accompany the learning activity and precede it.

Emotions and needs are interconnected. Emotions express positive or negative evaluation by the person of objects and phenomena significance as well as his own actions for satisfaction of his needs.

Emotions are closely related to motives. The function of motivation processes is to induce a person to a certain activity. The function of emotional processes is reflection, adjustment of motivational processes. These processes are supported by the characteristics of the emotional climate necessary to create and maintain the motivation for learning.

For students to search for ways of self-improvement in the learning process, emotions with a negative sign (not identical to a negative attitude towards learning) must be present, which are necessarily replaced by positive emotions. This is necessary because negative emotions not only disorganize the activities that lead to their emergence, but also organize activities that will reduce or eliminate the emergence of negative emotions, cause positive emotions.

9 Павлова І.Г. Становлення емоційної зрілості в підлітковому та юнацькому віці : автореф. дис. ... канд. псих. наук : спец. 19.00.07 ; ПДПУ ім. К.Д. Ушинського. Одеса, 2005. 20 с. 
Schizoid type. Its most essential feature is isolation. These adolescents are not very attracted to their peers; they prefer to be alone, to be in the company of adults. "Mental loneliness does not even weigh on the schizoid teenager who lives in his own world, with his unusual interests for children of this age". Such adolescents often demonstrate outward indifference to other people, lack of interest in them. They do not understand well the states of other people, their experiences, do not know how to sympathize. Their inner world is often filled with various fantasies, special hobbies. In the outward manifestation of their feelings, they are quite restrained, not always understandable to others, primarily for their peers, who, as a rule, do not like them very much.

Epileptoid type. These teenagers often cry, harass others, especially in early childhood. "Such children love to torture animals, beat and tease the younger and the weak, mock the helpless and unable to fight back. In the children's company, they claim not just leadership, but the role of a ruler. In the group of children they control, such adolescents establish their own rigid, almost terrorist orders, and their personal power in such groups rests mainly on the voluntary submission of other children or on fear. Under the conditions of a tough disciplinary regime, they often feel at their best, "they know how to please their bosses, achieve certain advantages, seize $\langle\ldots\rangle$ posts that give them <...> power, establish a dictate over others".

Hysteroid type. The main feature of this type is egocentrism, a thirst for constant attention to oneself. In adolescents of this type, a tendency to theatricality, posturing, and drawing is expressed. Such children find it difficult to endure when their companion is praised in their presence, when others are given more attention than themselves. "The desire to attract eyes, to listen to delight and praise, becomes for them an urgent need". Such adolescents are characterized by claims to an exceptional position among their peers, and in order to influence others, to attract attention to themselves, they often act in groups as instigators and instigators. At the same time, being unable to act as real leaders and organizers of the business, to gain an informal authority, they often and quickly fail. Inconsistency, inconsistency in statements and actions, due to their affective logic (the direction and content of judgments depend on the mood), usually leads to conflicting relationships in the group.

Paranoid. The dominant character trait of this type is a high degree of determination. Such a teenager subordinates his life to the achievement of a certain goal (and of a sufficiently large scale), while he is able to neglect the interests of the people around him, including his parents. To achieve his goal, he is able to give up well-being, entertainment, and 
comfort. Along with high energy, independence, self-reliance, aggressiveness, irritability, and anger are inherent in him when he meets an obstacle on the way to achieving his goal.

It is relatively rare in adolescents that there is a torpid (stiff) type of character accentuation. These adolescents are notable for their slowness and inertia of thought processes: they do not immediately switch from one topic to another, do not immediately "grasp" the educational material and therefore may lag behind in their studies if they are not previously familiar with the material. However, these adolescents are distinguished by good working capacity, accuracy, pedantry, and this gives them the opportunity to study successfully.

In their behaviour, they are slow, prone to emotional "stuck" and at the same time sometimes to strong affective outbursts. They get used to a certain way of life, to the same environment, to people, and any change causes them dissatisfaction. In career guidance, such adolescents should be recommended those professions that require perseverance, focused attention and stereotyped operations, and should not recommend professions that require quick switches, changes in work.

\section{SUMMARY}

The article is devoted to the study of the psychological and pedagogical aspects of the formation of the psychoemotional sphere of adolescents in the modern educational environment. The definition of the essence of the concept of "emotions" is given, their meaning for the mental development of the child is revealed. The main psychological characteristics of adolescence are considered. A brief description of some types of accentuation of the character of adolescents and recommendations for interaction with adolescents of the corresponding type are presented. The influence of the age characteristics of adolescents on the learning process in institutions of general secondary education is analysed. The concept of "emotional maturity" and the factors of its formation in adolescence are disclosed. Internal factors include the individual characteristics of a person, individual typological characteristics of the personality, the formation of an adequate "Iconcept". External factors include the level of social and environmental stability, the speed of changes in the system of social roles, the quality of family interaction, social circle, and frequency of social contacts.

\section{References}

1. Гамезо М.В., Домашенко И.А. Атлас по психологии : информационно-методические материалы к курсу «Общая 
психология» : учебное пособие для студентов педагогических институтов. Москва : Просвещение, 1986. 272 с.

2. Изард К. Эмоции человека / пер. с англ. Москва : изд-во МГУ, 1980. $440 \mathrm{c}$.

3. Колесов Д.В., Мягков И.Ф. Учителю о психологии и физиологии подростка. Москва : Просвещение, 1986. 80 с.

4. Кондрашова Л.В., Соколова Л.Е. Формирование эмоциональной культуры старшеклассников средствами учебновоспитательного процесса. Кривой Рог, 1994. 86 с.

5. Кулибали С. Особенности эмоциональной сферы в норме и патологии : автореф. дисс. ... канд. псих. наук : спец. 19.00.01; Институт психологии АПН Украины. Киев, 1995. 24 с.

6. Лесгафт П.Ф. Избранные педагогические сочинения / сост. И.Н. Решетень. Москва : Педагогика, 1998. 400 с.

7. Павлова І.Г. Становлення емоційної зрілості в підлітковому та юнацькому віці : автореф. дис. ... канд. псих. наук : спец. 19.00.07 ; ПДПУ ім. К.Д. Ушинського. Одеса, 2005. 20 с.

8. Психология эмоций / под ред. В.К. Вилюнаса, Ю.Б. Гиппенрейтер. Москва : изд-во МГУ, 1984. 288 с.

9. Рубинштейн С.Л. Основы общей психологии. Москва, 1946. $430 \mathrm{c}$.

10.Ушинский К.Д. Сочинения : в 9 т. Москва, 1950. Т. 2 : Человек как предмет воспитания. С. 117-118.

11.Ямницкий B.M. Влияние эмоциогенных ситуаций на творческую деятельность учащихся : дисс. ... канд. псих. наук : спец. 19.00.07. Одесса, 1993. 244 с.

Information about the authors: Bartienieva I. A.,

Candidate of Pedagogical Sciences, Senior Lecturer at the Department of Pedagogy South Ukrainian National Pedagogical University named after K. D. Ushynsky 26, Staroportofrankivska str., Odesa, 65020, Ukraine

Nozdrova O. P.,

Candidate of Pedagogical Sciences,

Senior Lecturer at the Department of Pedagogy South Ukrainian National Pedagogical University named after K. D. Ushynsky 26, Staroportofrankivska str., Odesa, 65020, Ukraine 